Ciba Foundation Symposium 175

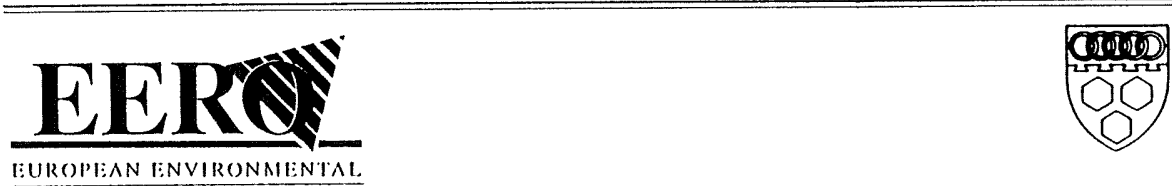

IEUROPIEAN IENVIRONMIENTAL

RISEISARCII ORGANISATION

\title{
ENVIRONMENTAL CHANGE AND HUMAN HEALTH
}

A Ciba Foundation Symposium jointly with the European Environmental Research Organisation

A Wiley-Interscience Publication

R. Rabbinge, H. C. van Latesteijn and J. Goudriaan Assessing the greenhouse effect in agriculture $\quad 62-76$

Discussion 76-79

JOHN WILEY \& SONS

Chichester - New York · Brisbane - Toronto · Singapore 


\title{
Assessing the greenhouse effect in agriculture
}

\author{
R. Rabbinge*†, H. C. van Latesteijn* and J. Goudriaan† \\ *Netherlands Scientific Council for Government Policy (WRR), PO Box 20004, 2500 EA \\ The Hague and †Department of Theoretical Production Ecology, Wageningen Agricultural \\ University, PO Box 430, 6700 AK Wageningen, The Netherlands
}

\begin{abstract}
Evidence that concentrations of $\mathrm{CO}_{2}$ and trace gases in the atmosphere have increased is irrefutable. Whether or not these increased concentrations will lead to climate changes is still open to debate. Direct effects of increased $\mathrm{CO}_{2}$ concentrations on physiological processes and individual plants have been demonstrated and the consequences for crop growth and production under various circumstances are evaluated with simulation models. The consequences of $\mathrm{CO}_{2}$ enrichment are considerable under optimal growing conditions. However, the majority of crops are grown under sub-optimal conditions where the effects of changes in $\mathrm{CO}_{2}$ are often less. The same holds for the possible indirect effects of environmental changes such as temperature rise. Studies on individual plants under optimal conditions are therefore not sufficient for evaluating the effects at a farm, regional, national or supra-national level. Simulation studies help to bridge the gap between the various aggregation levels and provide a basis for various studies of policy options at various aggregation levels.
\end{abstract}

1993 Environmental change and human health. Wiley, Chichester (Ciba Foundation Symposium 175) p 62-79

The effects on plant growth of changes in ambient $\mathrm{CO}_{2}$ have been investigated under experimental conditions. However, the effects on agricultural production cannot be assessed on the basis of these experimental results. Agricultural production is susceptible to a large number of environmental changes. Soil, air and water pollution as well as soil degradation and erosion may all cause a decline. The threat of global climate change has added another major concern to this list. Most research efforts, however, are directed towards understanding physiological effects at the subcellular level or at the level of individual plants. In these studies it is assumed that plants grow under optimal conditions. Most productive plants grow under circumstances where some of the conditions for optimal growth are not satisfied; for example, there may be shortage of water or nutrients or there may be pest infestation, and growth is restrained by one of these conditions. In such situations the effects of climate change may be 
considerably smaller than those predicted on the basis of research results under experimental conditions.

Changes in $\mathrm{CO}_{2}$ are only one aspect of climate change. Changes in temperature, radiation and precipitation may also occur, complicating the assessment of the net effects. The direct effects of these changes on crop growthdefining factors and indirect effects exerted through growth-limiting and growthreducing factors are investigated at the level of individual plants and at the crop level. The possible effects of climate change on agriculture as a socio-economic sector operate at farm, regional, national and supra-national levels, where the consequences of other changes may be much more important. To assess the net effects of climate change an integrative methodology is necessary. This can be provided by a multiple goal linear programming technique designed to integrate the various changes and to evaluate their relative effects. The results of this assessment can be used to help in the development of policy options.

\section{Environmental conditions and environmental changes}

For many centuries there have been slow but persistent changes in atmospheric $\mathrm{CO}_{2}$ concentration and temperature. Changes, as such, are therefore normal and should not lead to any problems. However, the change of ambient $\mathrm{CO}_{2}$ concentration which occurred during the last century was bigger than that of the previous 10000 years. This rapid change has also been found for various other trace gases, such as methane $\left(\mathrm{CH}_{4}\right)$, nitrous oxide $\left(\mathrm{NO}_{x}\right)$ and ozone $\left(\mathrm{O}_{3}\right)$. Since pre-industrial times the concentrations of these trace gases have increased by between $15 \%$ and $200 \%$. Chlorofluorocarbons (CFCs) are an entirely new, artificial addition.

It is likely that this trend will continue at a similar or perhaps even faster pace in the future. Since the end of World War II annual emissions of $\mathrm{CO}_{2}$ have increased by more than $300 \%$. The rates of increase have been especially high in the People's Republic of China and developing countries in south Asia, Africa and Latin America. By 1990 these countries were responsible for more than $25 \%$ of the global emission, whereas in 1950 they were responsible for about $7 \%$. The relative contribution of these areas will increase considerably during the coming decades as a result of population growth, a tremendous increase in combustion of fossil fuel, and deforestation. If all fossil carbon available for combustion is burned, the ambient $\mathrm{CO}_{2}$ concentration will increase up to a maximum of about 2000 p.p.m. This will take about 200 years. After that, the $\mathrm{CO}_{2}$ concentration will decrease again through geological and biological processes. Although the consequences on a human time-scale might be devastating, on a geological time scale this is merely a ripple on the water.

The increase in atmospheric $\mathrm{CO}_{2}$ may intensify the greenhouse effect, which may lead to a rise in overall mean temperature world-wide. This prediction is not based on extrapolation of current trends, but on energy balance climate models. 
The outcomes are uncertain and the size of the projected temperature increase differs between models, but virtually all the models predict an increase. It seems that temperature will increase, but the magnitude is uncertain. Even more uncertain are predictions about rainfall, cloudiness and radiation intensity in various places.

\section{Agricultural production}

Agriculture may be defined as the human activity that produces primary products with the sun as the major source of energy. The role of agriculture has changed considerably since its beginnings. Over the last century particularly there has been a significant increase in productivity per unit of area and per person. Since World War II there has been a sharp rise in productivity growth in all agricultural areas as a result of better manipulation of agricultural factors. On average, the productivity growth used to be 3 to $4 \mathrm{~kg} / \mathrm{ha} /$ year and changed to more than $50 \mathrm{~kg} / \mathrm{ha} /$ year in a very short period.

This change has been found everywhere, independent of the socio-economic system or climate zone. The combination of knowledge from various disciplines and the new methods, especially the application of external inputs such as plant nutrients and pesticides, help to increase productivity. In parts of the industrialized world productivity has risen from $1500 \mathrm{~kg}$ wheat (Triticum spp. L.) per ha early this century to $8000 \mathrm{~kg} / \mathrm{ha}$ at present. In about 80 years labour productivity improved from 200 hours/tonne to 2 hours/tonne.

Yields may be considered at different levels: potential, attainable and actual (Rabbinge 1986). The potential yield is determined solely by yield-defining factors and the physiological, phenological, geometrical and optical characteristics of the crop. The physiological characteristics determine the way light energy is used to produce the sugars which constitute the basis for all structural materials in the crop. The geometrical and optical characteristics determine what fraction of the incoming radiation is intercepted and absorbed. The phenological characteristics determine, according to temperature, the rate at which various development stages are passed.

The attainable yield is lower because crop growth-limiting factors such as nutrient or water shortage occur. During a part of the growing season water or nutrients may be restricted, resulting in a decrease in yield. More than $90 \%$ of agriculture takes place under such circumstances. The actual yield is even lower as a result of crop growth-reducing factors such as pests, diseases, weeds or air pollution.

The yield-defining factors determine the potential for primary production. They can be affected or changed little by management decisions, because environmental conditions such as incoming radiation, temperature and $\mathrm{CO}_{2}$ concentration can not be manipulated by the individual farmer. The yieldlimiting factors (water and nutrients) as well as the yield-reducing factors (pests) 


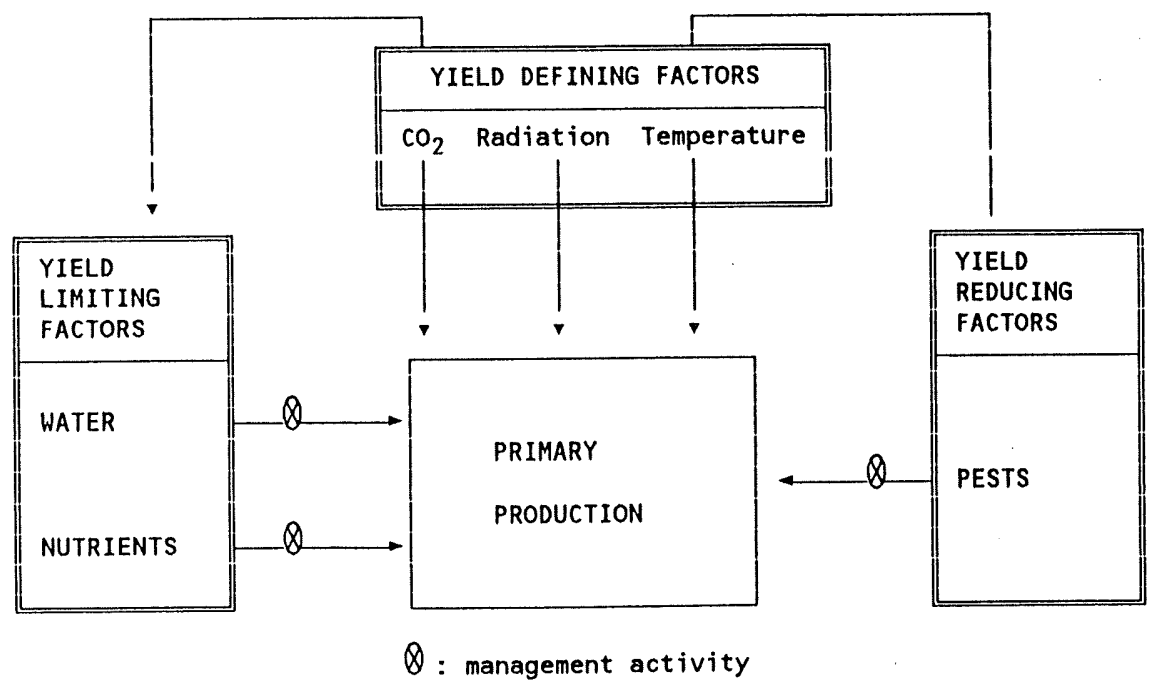

FIG. 1. The influence of climatic variables on agricultural production. Stages at which management decisions can have an effect are indicated $(\otimes)$.

can be influenced by management decisions. The interactions between these factors are schematically represented in Fig. 1.

An increase in atmospheric $\mathrm{CO}_{2}$ will have a primary physiological effect on production by increasing photosynthetic activity (Lemon 1983, Goudriaan 1990). Although the initial positive response to an increased $\mathrm{CO}_{2}$ concentration has been demonstrated convincingly, there are uncertainties about long-term effects.

In addition to this primary effect, changes in temperature, radiation and precipitation may have secondary effects on plants. An increase in temperature would speed up development, thus shortening the growth period, and would therefore have a negative effect on yields for determinate crops (those which have a clear period of productive growth, such as wheat) (Nonhebel 1990), but would probably increase yields of indeterminate species (those which grow productively over nearly the whole growing season, such as grass) (Squire \& Unsworth 1988). Changes in radiation can complicate this effect. Increased cloud cover might have a negative effect on production during the growth period. Uncoupling of present temperature-photoperiod complexes would probably lead to changes in the geographical distribution of perennial species (Habjorg 1990).

A change in precipitation (temporal or geographical) can have positive or negative effects on local production potentials, depending on the shifts in water availability (Rabbinge 1986). This can of course be compensated by management responses, such as an increase in irrigation or drainage activities. A temperature rise combined with changes in water availability can affect availability of nutrients because of changes in mineralization in the soil which can induce deeper 
drainage and possible leaching of nitrates. Finally, as a result of changes in temperature, pests can shift. For example, the cornborer, Ostrinia nubilalis, will tend to spread more to the northern regions, introducing new problems in maize production that require changes in pest management. The net effect of all these changes cannot be predicted with current knowledge (Parry 1990).

\section{Direct effects of climate change on photosynthesis}

There is a great deal of experimental evidence available on the effect of ambient $\mathrm{CO}_{2}$ concentration on photosynthesis and the subsequent accumulation of dry matter in crops (Lemon 1983, Strain \& Cure 1985, Kimball 1983, Cure \& Acock 1986). Light is indispensable for the process of photosynthetically driven $\mathrm{CO}_{2}$ uptake by green plants. In the natural environment, light and $\mathrm{CO}_{2}$ are normally sub-optimal; consequently, photosynthesis is stimulated by an increase of ambient $\mathrm{CO}_{2}$ (Fig. 2), not only under high light intensity, but also under low light conditions.

There are clear differences between two major classes of plants, $\mathrm{C}_{3}$ and $\mathrm{C}_{4}$ plants, which differ in biochemical and anatomical aspects in the way they take up and utilize $\mathrm{CO}_{2}$ from the ambient air. In $\mathrm{C}_{3}$ plants the enzyme that binds $\mathrm{CO}_{2}$ can also be inhibited by $\mathrm{O}_{2}$ (Farquhar \& von Caemmerer 1983). Enzyme bound to $\mathrm{O}_{2}$ must be recovered. This recovery costs energy and releases $\mathrm{CO}_{2}$, observable as photorespiration. Because $\mathrm{CO}_{2}$ and $\mathrm{O}_{2}$ compete for the same site on the enzyme, photorespiration is suppressed by higher $\mathrm{CO}_{2}$; higher $\mathrm{CO}_{2}$ concentrations will lead to a higher proportion of $\mathrm{CO}_{2}$ binding the enzyme and thus to a higher rate of photosynthesis. In $\mathrm{C}_{4}$ plants, mostly tall tropical grasses such as millet (Panicum miliaceum L.), maize (Zea mays L.), sorghum (Sorghum bicolor [L.] Moench) and sugar-cane (Saccharum officinarum L.), the enzyme which binds $\mathrm{CO}_{2}$ does not bind $\mathrm{O}_{2}$. Higher levels of ambient $\mathrm{CO}_{2}$ will therefore have no effect on the process of photosynthesis through this route. However, photosynthetic activity may be influenced by partial stomatal closure, a typical secondary effect of an increase in ambient $\mathrm{CO}_{2}$. Stomatal pores in the epidermis of leaves are necessary for the uptake of $\mathrm{CO}_{2}$ from the ambient air, but at the same time water vapour escapes (transpiration). The degree of opening can be considered as a compromise in the balance between limitation of water loss and admission of $\mathrm{CO}_{2}$. The generally observed closure of stomata when $\mathrm{CO}_{2}$ increases is an expression of this compromise (Wong 1979). The much higher affinity of the $\mathrm{CO}_{2}$-binding enzyme for $\mathrm{CO}_{2}$ in $\mathrm{C}_{4}$ plants permits them to maintain a more favourable ratio between net $\mathrm{CO}_{2}$ uptake and evaporation of water.

If ambient $\mathrm{CO}_{2}$ is raised, net $\mathrm{CO}_{2}$ assimilation may be increased and water loss may be reduced, depending on how the stomata react. Figure 2 shows the $\mathrm{CO}_{2}$ supply-demand function of assimilation. The figure shows how the assimilation rate is affected by the $\mathrm{CO}_{2}$ concentration in the stomatal cavities 


\section{(a) $C_{3}$ species response}

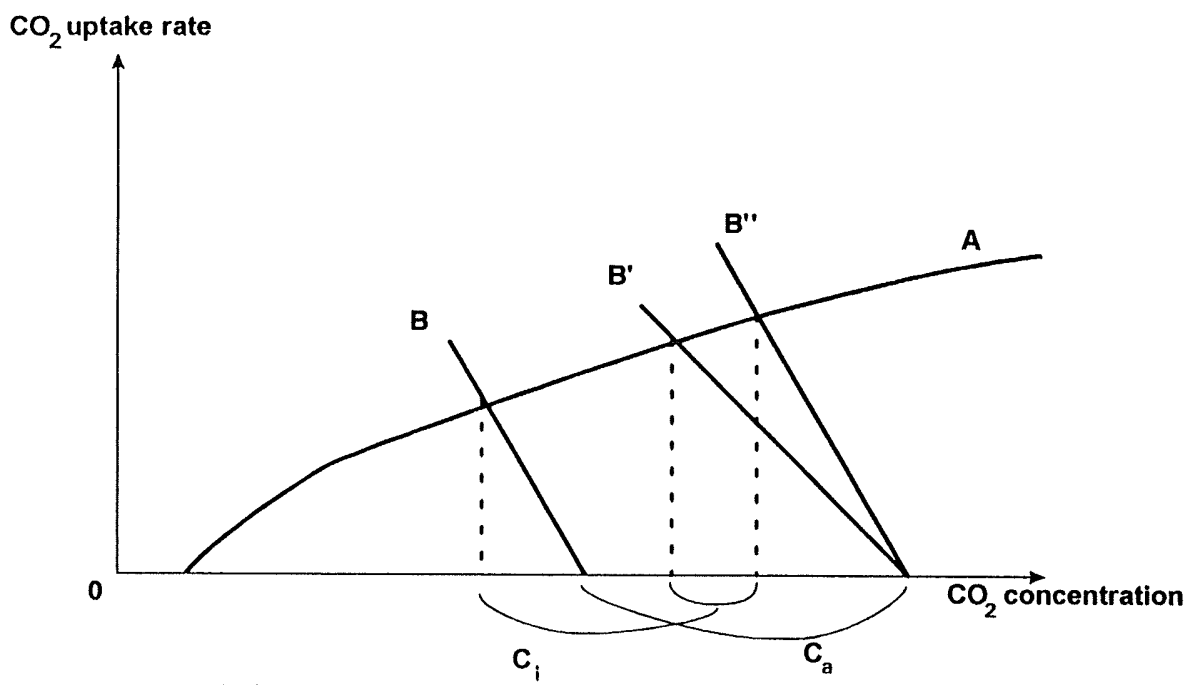

(b) $\mathrm{C}_{4}$ species response

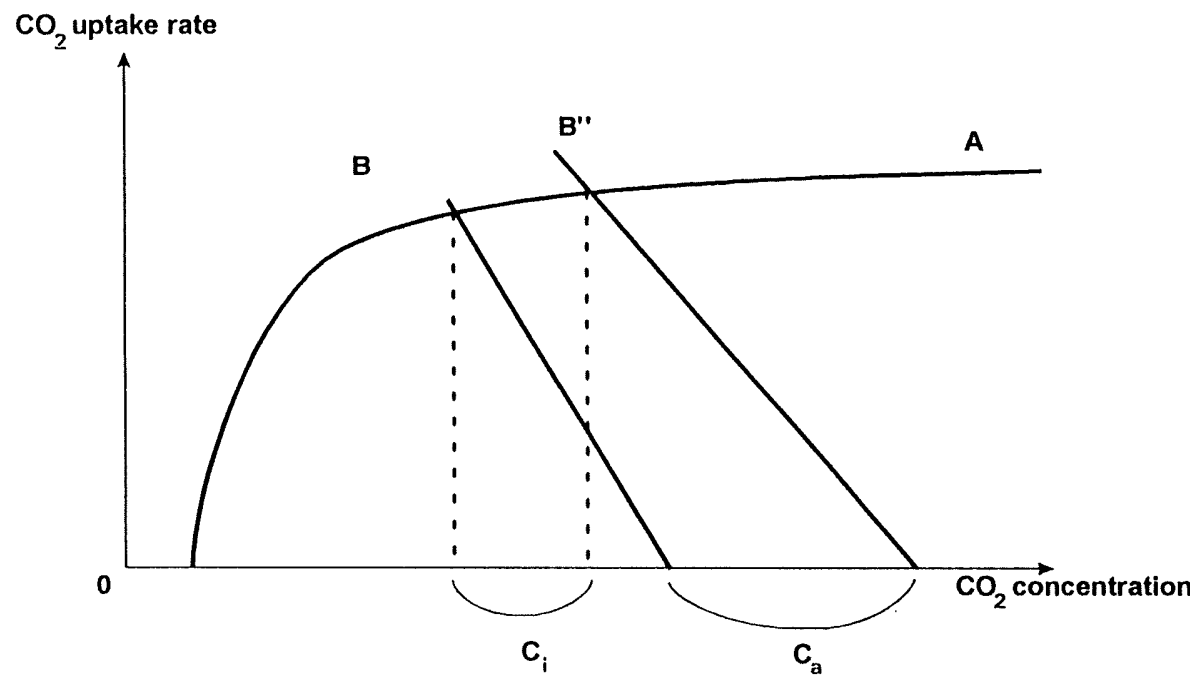

FIG. 2. The response (A) in (a) $\mathrm{C}_{3}$ plants, which show a strong assimilation response to $\mathrm{CO}_{2}$, and (b) $\mathrm{C}_{4}$ plants, which show an assimilation response only at a low $\mathrm{CO}_{2}$ concentration, of leaf photosynthesis to the concentration of $\mathrm{CO}_{2}$ inside the stomatal cavity $\left(C_{i}\right)$. The rate of photosynthesis affects $C_{i}$ through stomatal supply limitation (B). Lines $\mathrm{B}^{\prime}$ and $\mathrm{B}^{\prime \prime}$ indicate the effects of a doubling of $\left[\mathrm{CO}_{2}\right]$ with no stomatal response $\left(\mathrm{B}^{\prime}\right)$ and with partial stomatal closure $\left(\mathrm{B}^{\prime \prime}\right)$ resulting from the increase in $\mathrm{CO}_{2}$. Adapted from Goudriaan \& Unsworth (1990). 
(line A). This intercellular concentration decreases linearly from the ambient $\mathrm{CO}_{2}$ concentration when the assimilation rate increases (line $\mathrm{B}$ ), because of the resistance offered by the stomata. The point of intersection of the two lines (line $\mathrm{B}$ with line A) gives the realized rate of assimilation and intercellular $\mathrm{CO}_{2}$ concentration. Raising external $\mathrm{CO}_{2}$ will increase assimilation to a maximum (line $\mathrm{B}^{\prime}$ ) if the stomata do not respond at all, but the stomata usually close somewhat (line $\mathrm{B}^{\prime \prime}$ ). In an extreme situation where the intercellular $\mathrm{CO}_{2}$ concentration is kept constant, when ambient $\mathrm{CO}_{2}$ increases the stomatal closure will be maximal; as a result there will be no effect on assimilation. However, the most common response is that the ratio of intercellular $\left(\mathrm{C}_{\mathrm{i}}\right)$ to external $\mathrm{CO}_{2}\left(\mathrm{C}_{\mathrm{a}}\right)$ concentrations is stabilized, thereby balancing $\mathrm{CO}_{2}$ assimilation and water loss. This constant $C_{i}: C_{a}$ ratio means that the stomatal aperture is reduced very little if assimilation responds strongly to $C_{i}$ (typical in $\mathrm{C}_{3}$ plants). In $\mathrm{C}_{4}$ plants photosynthetic $\mathrm{CO}_{2}$ uptake is usually almost saturated, and stomatal closure is maximal (Fig. 2b). The combined effect can be summarized as follows: typically with a doubling of $C_{a}$, in $C_{3}$ plants transpiration will be reduced by $10-20 \%$ and assimilation stimulated by $40 \%$, and in $\mathrm{C}_{4}$ plants only transpiration will be reduced, by up to about $25 \%$. In both types this leads to a considerable increase in efficiency of water use.

\section{Effects of an increase in ambient $\mathrm{CO}_{2}$ concentration on crop production}

\section{Net effects under optimal conditions}

During the growing season, several internal mechanisms operate in the plant, modifying the initially observed effects of $\mathrm{CO}_{2}$. In plants adapted to high $\mathrm{CO}_{2}$, photosynthesis per unit leaf area is often smaller (Wong 1979, Mortensen 1983) than in non-adapted plants (when measured under equal circumstances), but in soy bean (Glycine max [L.] Merr.) increased photosynthetic capacity has been observed (Valle et al 1985, Campbell et al 1988). When grown and at a higher $\mathrm{CO}_{2}$ concentration, leaves generally have a higher rate of photosynthesis. This is particularly true for $\mathrm{N}_{2}$-fixing plants, which have nodules in their rooting system. The growth response of these plants to $\mathrm{CO}_{2}$ tends to be particularly strong.

Starch accumulation (Ehret \& Jolliffe 1985) tends to cause some increase of leaf weight per unit leaf area. This rather passive response will not increase light interception, but the more active response of formation of more leaf area, by producing larger leaves or more tillers, will further enhance the effect of increased $\mathrm{CO}_{2}$ at the level of a whole crop.

As shown in a review by Kimball (1983), responses to $\mathrm{CO}_{2}$ at the single leaf level are carried over to crop yield; the response to a doubling of $\mathrm{CO}_{2}$ concentration is a mean increase in dry matter of $40 \%$ for $\mathrm{C}_{3}$ crops and $15 \%$ for $\mathrm{C}_{4}$ crops. 
Net effects with water shortage

The effect of raised $\mathrm{CO}_{2}$ under good growing conditions is maintained fully under conditions of water shortage. Gifford (1979) and Sionit et al (1980) have shown that growth, yield and efficiency of water use of wheat under water shortage can be considerably improved by raised ambient $\mathrm{CO}_{2}$. Kimball et al (1986) reported that a doubling of $\mathrm{CO}_{2}$ concentration led to relative increases of cotton (Gossypium hirsutum L.) production ranging between $50 \%$ and $70 \%$ with both optimal and limiting levels of water supply. Similarly, Goudriaan \& Bijlsma (1987) showed that efficiency of water use in Faba bean (Vicia faba L.) was improved by about $50 \%$ under doubled $\mathrm{CO}_{2}$, with both normal and limited water supply. For a $C_{4}$ grass, however, Gifford \& Morison (1985) found that growth was stimulated by $\mathrm{CO}_{2}$ only under severe water stress.

In conditions of high salinity plants grow continually under osmotic stress. Schwarz \& Gale (1984) found that the $\mathrm{CO}_{2}$-induced increase of dry matter in saline conditions was equally strong as or even more pronounced than in nonsaline situations, and that $\mathrm{C}_{4}$ halophytes (plants that are salt tolerant) responded as strongly as $\mathrm{C}_{3}$ halophytes.

A major reason for the strong positive effect of $\mathrm{CO}_{2}$ in plants subjected to water stress is the common physical pathway of water vapour and $\mathrm{CO}_{2}$ through the stomatal pores. The effect might partly be explained by better availability of assimilates with which to make osmotic adjustments and thereby maintain turgor. These results are especially important for arid regions, where brackish or even saline conditions are common. Even when a limited stock of water is available, the plants may have adequate water for most of the growing period. The water shortage occurs only when the soil has lost about $75 \%$ of its initial water content. An increased efficiency of water use will result in a greater biomass in proportion to the amount of water used, but the amount of water left in the soil will be unchanged. However, if the plants are also limited by nutrient shortage or by the duration of the development period, the increase in biomass will be too small to compensate for the decreased transpiration rate and the amount of water left in the soil after the growing period may increase.

\section{Net effects with nutrient shortage}

Nutrient shortage tends to limit crop growth more than water shortage, and without leaving much room for stimulation by $\mathrm{CO}_{2}$. Increased accumulation of starch in leaves grown under high $\mathrm{CO}_{2}$ gives a general increase in dry matter. Shortage of phosphorus was found to limit growth almost independently of $\mathrm{CO}_{2}$ in a pot experiment (Goudriaan \& de Ruiter 1983). Also, the growthlimiting effect of potassium shortage is not alleviated by higher $\mathrm{CO}_{2}(\mathrm{~J}$. Goudriaan, unpublished data 1985). In open soil and perennial species a positive effect of increased $\mathrm{CO}_{2}$ concentration might occur through more intense rooting and increased soil weathering (Rosenberg 1981). 
Norby et al (1986) could not find a disappearance of the positive effects of a $\mathrm{CO}_{2}$ increase, even at very low nutrient levels. However, the effect of $\mathrm{CO}_{2}$ enrichment under such conditions is much less, because nutrient shortage limits growth. Nitrogen appears to be in an intermediate position; increased $\mathrm{CO}_{2}$ has a small positive effect even under rather severe nitrogen shortage (Goudriaan $\&$ de Ruiter 1983). In addition to increased starch accumulation, which generally lowers leaf nutrient contents, there is also a decrease in the carboxylation enzyme rubisco (ribulose-bisphosphate carboxylase), which contains up to $50 \%$ of leaf nitrogen. In accordance with this photosynthetic role of nitrogen, the nitrogen content of leaf tissue is lower in plants grown under high $\mathrm{CO}_{2}$ than under low $\mathrm{CO}_{2}$. In seed tissue, however, the $\mathrm{C}: \mathrm{N}$ ratio is more stable (Kimball et al 1986).

An intriguing question is how canopy transpiration is affected by $\mathrm{CO}_{2}$ when plant growth is nutrient-limited. Lenssen (1986) showed that the reduction in transpiration caused by an increase in $\mathrm{CO}_{2}$ was the same under severe phosphorus limitation. This result is relevant with regard to water yields from watersheds with naturally growing vegetation. These natural ecosystems are quite often strongly nutrient-limited. Growth is not improved under conditions of increased $\mathrm{CO}_{2}$ because of nutrient limitations, but an increase in the water yields may be expected.

\section{Net effects of changes in temperature and the growing season}

As indicated above, with a temperature rise the rate of development of crops may increase and the length of the growing season will be shortened, especially for determinate crop species. Unless a temperature rise is very high, the decrease in yield it causes is more than compensated by the effect of $\mathrm{CO}_{2}$ enrichment. The effects of a temperature rise on pests and diseases are very uncertain because primary pests may increase in number but so might their natural enemies.

\section{The influence of other climatic factors}

Other climatic factors such as precipitation and radiation are no less important than temperature (Rosenberg et al 1990). Unfortunately, there is even more uncertainty about the way they will change than there is about the likely change in temperature. Crop growth models show that potential productivity is closely related to incoming radiation during the growing season, but the general circulation models (GCMs) that are used for climate forecasting are not yet able to produce reliable predictions on this point. The possible impact of radiation changes is therefore usually ignored, in spite of their potential importance.

The current prediction is that mean global precipitation will increase by $7-15 \%$ (Wilson \& Mitchell 1987). Some regional specificity can be obtained from maps such as those produced by Schlesinger \& Mitchell (1985). A model for wheat and rice that included both climatic changes (temperature and precipitation) 
and the physiological effects of doubled $\mathrm{CO}_{2}$ predicted that potential crop yields would increase by 10-50\% at some sites in Europe and Asia (van Diepen et al 1987). The mean GCM scenarios were superimposed on current weather, retaining current variability. The resulting variability in yield was less than found presently, so more stable wheat yields can be expected.

The effects of climate change at the level of individual farms, regions and countries, and implications for policy-making

As a result of accelerating changes in technology and its dissemination, changing relations within the global market for agricultural products and adaptations in policy, the agricultural sector will show major structural alterations in the near future. The implicatious of climatic changes for management and policy cannot easily be singled out. A clear understanding of the overall developments in agriculture is indispensable for the formulation of appropriate policy reactions to climate changes. This is illustrated by the increase in the world-wide average grain yield per unit area that occurred between 1959 and 1986 . In this period the yields increased from $1400 \mathrm{~kg} / \mathrm{ha}$ to about $2600 \mathrm{~kg} / \mathrm{ha}$ (Food and Agriculture Organization of the United Nations [FAO] 1987). This near doubling was the result of a continued annual relative growth rate of about $2.3 \%$ per year. Over the same period, atmospheric $\mathrm{CO}_{2}$ rose from 315 to about 345 p.p.m., at an average rate of about $0.34 \%$ per year. When yields over this period are plotted against atmospheric $\mathrm{CO}_{2}$ concentrations, an almost perfect correlation is evident (Fig. 3). It would be very unwise indeed to draw any conclusions from this graph about cause and effect, but it does raise some interesting considerations.

Figure 3 shows that the relative growth rate of cereal production (on an area basis) has been seven times as large as the increase in atmospheric $\mathrm{CO}_{2}$. We know from experiments that under optimal conditions for growth $1 / 14$ at most of this increase in crop production can be reasonably ascribed to the increase in atmospheric $\mathrm{CO}_{2}$. This relatively small impact of the rise in $\mathrm{CO}_{2}$ strengthens the point of view of those who consider the climatic change issue to be minor in comparison with other opportunities and threats of human origin.

The yields from individual farms have increased considerably over the last decades, mainly because of improved farm management and the proper use of external inputs. There is still ample room for further rises in actual yields; in many cases, the actual yield is only $10-20 \%$ of the potential yield. Whether or not these potential yields will be achieved is dependent to a great extent on policy decisions. It is for that reason that the assessment of the consequences of climate change for the agricultural sector should include the options for future developments of agriculture at a regional, national or supra-national level.

One way to provide this sort of information is to assess the quantitative relations between changes in climatic conditions and a number of self-contained 


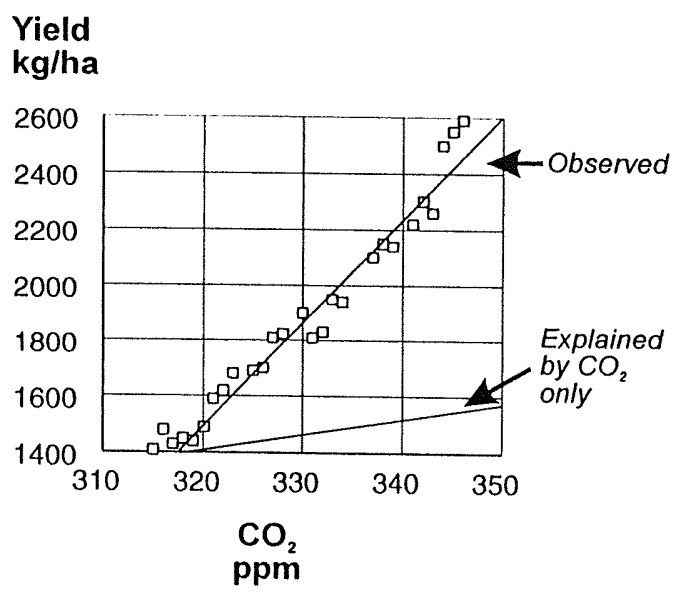

FIG. 3. Average world-wide grain yields (Observed) and the yield increase calculated to result from increased ambient $\mathrm{CO}_{2}$ between 1959 and 1986 versus atmospheric $\mathrm{CO}_{2}$ concentration measured at Mauna Loa, Hawaii. Adapted from Goudriaan \& Unsworth (1990).

technical developments in agriculture. These technical relations limit the possibilities for future developments. Next to that a set of objectives can be identified which play an important role in the policy debate on the future of agriculture. These objectives are related to agricultural production itself, but also to other socio-economic aims, criteria with respect to environmental protection and requirements for nature conservation. The consequences of interactions and preferences among the different objectives for rural areas can then be examined, given the technical possibilities and the expectations for climatic conditions. The large number of uncertainties make it impossible to construct a model that can predict changes in agriculture resulting from changes in climatic conditions. However, it is possible to construct a model that provides consistent information based on 'what if' questions. This methodology has been developed by the Netherlands Scientific Council for Government Policy and has been used to explore options for future land use in the European Community (Netherlands Scientific Council for Government Policy 1992, Rabbinge \& van Latesteijn 1992; van Latesteijn 1993). In this way, the relative importance of the effects of climate change on agriculture in comparison with changes that will result from policy changes can be assessed. For example, it might very well be that changes in agriculture related to environmental protection and nature conservation issues turn out to be much more profound than changes resulting from climate change.

Policy decisions intended to oppose the possible adverse effects of climate change must always be regarded in this broader context. It might be that compared with other issues climate change has only a minor impact on policies. 
Although there will always be a discrepancy between the policies suggested by results of rational research and the policy-making process in real life, assessment of the relative importance of climate change is a prerequisite for sound policy planning.

Coupling crop growth simulation models with land use models and providing this system with information on climate changes is one way in which to construct a methodological framework that can be used to assess the relative effects of climate change on agriculture. In a quantification of the possible developments and their interactions, land use must be the central theme; through changes in land use all other changes can be linked to each other. On the basis of soil characteristics, climatic conditions and the properties of the crop, regional yield potentials for indicator crops can be calculated using a dynamic crop simulation model and a geographical information system. Next, the influence of climate changes and policy preferences on the regional allocation of production can be assessed. In this way, the relative contribution of climate change to the available options for agriculture can be explored. This procedure is outlined in Fig. 4.

In general, the effects of climate change may be of minor importance. Nevertheless, this methodology may help us to gain better quantitative insight into the present options for land use and the changes resulting from climate change. In this way, the combination of biotechnical studies, which provide the basic information needed on all plant and crop levels, and socio-economic studies on objectives and constraints may generate land-use scenarios for long-term policies.

\section{Conclusions}

The effects of change in ambient $\mathrm{CO}_{2}$ on growth and production of crops growing under optimal contitions are considerable. Production may increase, water use efficiency improve and yield variability decrease. However, most crops

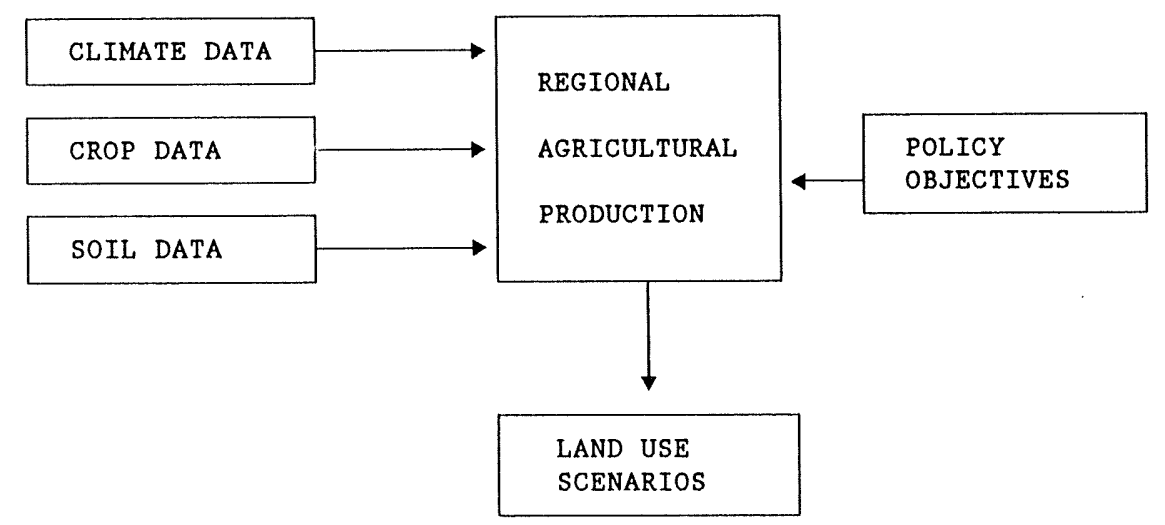

FIG. 4. The framework of research needed to assess the relative contribution of climatic change to available options for agriculture. 
grow under circumstances where water or nutrients limit growth and production. Under such circumstances the effects of climate change on agro-ecosystems will be much less prominent. Moreover, the possible effects of climate change on agriculture are outweighed by changes brought about by shifting policies. Stimulating agricultural production can easily lead to a doubling of output so that any effects of climate change would be overshadowed. Nevertheless, they are present and may alter the range of options available. An analytic methodology to evaluate the possible options for future land use and to demonstrate the consequences of various policies has been described. This methodology allows assessment of the relative importance of various changes and generates a set of feasible options for land use; the consequences of climate change for such options can be demonstrated.

We propose the following research agenda to improve the quality of such studies.

Climate change. There is an urgent need for consistent and complete pictures of climate change. Not only the certain effects, such as $\mathrm{CO}_{2}$ enrichment, but also the uncertain effects on temperature, precipitation and radiation in various agro-ecological zones should be included in such studies. There should be a regional breakdown of the results, ideally to the level of agro-climatic regions.

Impact assessment. The consequences of environmental change on basic physiological and phenological processes of plants, crops, pests and diseases should be quantified in more detail. This can be done through detailed studies under controlled conditions. Methods should be developed to study long-term effects because these may differ considerably from short-term effects.

Scenario studies. Studies on a higher integrative level, using scenario approaches, should be applied to explore various options for land use under changed climate conditions.

\section{References}

Campbell WJ, Allen LH, Bowes G 1988 Effects of $\mathrm{CO}_{2}$ concentration on Rubisco activity, amount, and photosynthesis in soybean leaves. Plant Physiol 88:1310-1316

Cure JD, Acock B 1986 Crop responses to carbon dioxide doubling: a literature survey. Agric For Meteorol 38:127-145

Ehret DL, Jolliffe PL 1985 Photosynthetic carbon dioxide exchange of bean plants grown at elevated carbon dioxide concentrations. Can J Bot 63:2026-2030

FAO 1987 FAO production yearbook. FAO, Rome

Farquhar DG, von Caemmerer S 1983 Encyclopedia of plant physiology, vol 12B: Modelling of photosynthetic response to environmental conditions. Springer-Verlag, New York

Gifford RM 1979 Growth and yield of carbon dioxide-enriched wheat under water-limited conditions. Aust J Plant Physiol 6:367-378 
Gifford RM, Morison JIL 1985 Photosynthesis, water use and growth of a C-4 grass stand at high $\mathrm{CO}_{2}$ concentration. Photosynth Res 7:77-90

Goudriaan J 1990 Primary productivity and $\mathrm{CO}_{2}$. In: Goudriaan J, van Keulen $\mathrm{H}$, van Laar $\mathrm{HH}$ (eds) The greenhouse effect and primary productivity in European agroecosystems. Pudoc, Centre for Agricultural Publishing and Documentation, Wageningen, $\mathrm{p} 23-26$

Goudriaan J, Bijlsma RJ 1987 Effect of $\mathrm{CO}_{2}$ enrichment on growth of faba beans to two levels of water supply. Neth J Agric Sci 35:189-191

Goudriaan J, de Ruiter $\mathrm{HE} 1983$ Plant growth in response to $\mathrm{CO}_{2}$ enrichment, at two levels of nitrogen and phosphorus supply. Neth J Agric Sci 31:157-169

Goudriaan J, Unsworth MH 1990 Implications of increasing carbon dioxide and climate change for agricultural productivity and water resources. In: Kimball BA (ed) Impact of carbon dioxide, trace gases and climate change on global agriculture. American Society of Agronomy, Madison, WI, p 111-130 (Spec Publ 53)

Habjorg A 1990 Effects of climatic changes on growth and development of North European plants. In: Goudriaan J, van Keulen H, van Laar HH (eds) The greenhouse effect and primary productivity in European agroecosystems. Pudoc, Centre for Agricultural Publishing and Documentation, Wageningen, p 11-16

Kimball BA 1983 Carbon dioxide and agricultural yield: an assemblage and analysis of 430 prior observations. Agron J 75:779-788

Kimball BA, Mauney JR, Radin JW et al 1986 Effects of increasing atmospheric $\mathrm{CO}_{2}$ on the growth, water relations, and physiology of plants grown under optimal and limiting levels of water and nitrogen. In: Response of vegetation to carbon dioxide. US Department of Energy and US Department of Agriculture, Washington, DC

Lemon ER (ed) $1983 \mathrm{CO}_{2}$ and plants: the response of plants to rising levels of atmospheric $\mathrm{CO}_{2}$. Westview Press, Boulder, $\mathrm{CO}$

Lenssen GM 1986 De invloed van $\mathrm{CO}_{2}$ in combinatie met fosfaatgebrek op de groei en de transpiratie van tarwe. MSc thesis, Wageningen Agricultural University, Wageningen

Mortensen LM 1983 Growth response of some greenhouse plants to environment. X. Long-term effect of $\mathrm{CO}_{2}$ enrichment on photosynthesis, photorespiration, carbohydrate content and growth of Chrysanthemum morifolium Ramat. Agricultural University of Norway, As (Sci Rep 272, vol 62)

Netherlands Scientific Council for Government Policy 1992 Ground for choices: four perspectives for the rural areas in the European Community. Sdu Publishers, The Hague (Rep Gov 42)

Nonhebel S 1990 The impact of changes in weather and $\mathrm{CO}_{2}$ concentration on spring wheat yields in western Europe. In: Goudriaan J, van Keulen H, van Laar HH (eds) The greenhouse effect and primary productivity in European agroecosystems. Pudoc, Centre for Agricultural Publishing and Documentation, Wageningen, p 48-51

Norby RJ, O'Neill EG, Luxmoore RJ 1986 Effects of atmospheric $\mathrm{CO}_{2}$ enrichment on the growth and mineral nutrition of Quercus alba seedlings in nutrient-poor soil. Plant Physiol (Bethesda) 82:83-89

Parry ML 1990 Climate change and world agriculture. Earthscan Publications, London

Rabbinge R 1986 The bridge function of crop ecology. Neth J Agric Sci 34:239-251

Rabbinge R, van Latesteijn HC 1992 Long-term options for land use in the European Community. Agric Syst 40:195-210

Rosenberg NJ 1981 The increasing $\mathrm{CO}_{2}$ concentration in the atmosphere and its implication on agricultural productivity. Clim Change 3:265-279

Rosenberg NJ, Kimball BA, Martin PH, Cooper CF 1990 From climate and $\mathrm{CO}_{2}$ enrichment to evapotranspiration. In: Waggoner PE (ed) Climate change and US water resources. Wiley, New York, p 151-175 
Schlesinger ME, Mitchell JFB 1985 Model projections of the equilibrium climatic response to increased carbon dioxide. In: MacCracken MC, Luther FM (eds) The potential climatic effects of increasing carbon dioxide. National Technical Information Service, Springfield, VA (DOE/ER0237, US Dep Energy, Wash, DC) p 81-147

Schwarz M, Gale J 1984 Growth response to salinity at high levels of carbon dioxide. J Exp Bot 35:193-196

Sionit N, Hellmers N, Strain BR 1980 Growth and yield of wheat under $\mathrm{CO}_{2}$ enrichment and water stress. Crop Sci 20:456-458

Squire GR, Unsworth MH 1988 Effects of $\mathrm{CO}_{2}$ and climatic change on agriculture, 1988. Report to the UK Department of Environment, University of Nottingham, Nottingham

Strain BR, Cure JD 1985 Direct effects of increasing carbon dioxide on vegetation. National Technical Information Service, Springfield, VA (DOE/ER0238, US Dep Energy, Wash, DC)

Valle R, Mishoe JW, Campbell WJ, Jones JW, Allen LH 1985 Photosynthetic responses of 'Bragg' soybean leaves adapted to different $\mathrm{CO}_{2}$ environments. Crop Sci 25:333-339

van Diepen CA, van Keulen H, Penning de Vries FWT, Noy IGAM, Goudriaan J 1987 Simulated variability of wheat and rice yields in current weather conditions and in future weather when ambient $\mathrm{CO}_{2}$ has doubled. $\mathrm{CABO}$, Wageningen (Intern Rep Centre Agrobiol Res Dep Theor Prod Ecol 14)

van Latesteijn HC 1993 A methodological framework to explore long-term options for land use. In: Penning de Vries FWT, Teng PS, Metselaar K (eds) Systems approaches for agricultural development. Kluwer, The Hague, p 445-455

Wilson CA, Mitchell JFB 1987 A doubled $\mathrm{CO}_{2}$ climate sensitivity experiment with a global climate model including a simple ocean. J Geophys Res A 92(D11):3315-3343

Wong SC 1979 Elevated atmospheric partial pressure of $\mathrm{CO}_{2}$ and plant growth. I. Interactions of nitrogen nutrition and photosynthesis in $\mathrm{C}_{3}$ and $\mathrm{C}_{4}$ plants. Oecologia 44:68-74

\section{DISCUSSION}

Sutherst: Are you making the assumption that the variability in climate will be unchanged in your climate change scenario?

Rabbinge: Yes, because we do not have any indication that the stability of the climate will decrease. We are certain that the $\mathrm{CO}_{2}$ concentration will increase, but are uncertain about the temperature increase. Therefore, we have taken into account the $\mathrm{CO}_{2}$ increase and the temperature increase separately and in combination.

Sutherst: So you are working with averages all the time.

Rabbinge: Yes, but we have also considered the variation in temperature and the consequences of that.

Oeschger: From discussions with biologists, I have the impression that although an increase of growth is initially expected or seen in response to an increased $\mathrm{CO}_{2}$ level, a saturation or even a deterioration might follow. Also, I showed (p 15) that deconvolution of the observed $\mathrm{CO}_{2}$ increase indicates only a minor non-fossil sink or source up to the present. 
Rabbinge: You're right that the long-term effects are not considered, but that's something we have little experience with. There may be adaptation to the higher carbon dioxide concentration, and that may affect other processes, physiological processes, but we are not yet sure of that. More experimental evidence is needed to confirm that the long-term effects are different from the immediate effects. The inmediate effects result from the basic processes, which can be exactly quantified and can be integrated into simulation models. With these models, you can evaluate the crop's response to climate change.

Mansfield: Do stomatal responses to $\mathrm{CO}_{2}$ and their effects on water use vary between different species or different cultivars?

Rabbinge: Within some plant groups there are different types of stomatal behaviour, but normally the differences are between groups of plants. Sunflowers, for example, are a typical example of a group of plants which always have open stomata, whereas the cucumber or the soya bean have regulated stomata. In wheat the stomatal regulation is such that the internal and external carbon dioxide concentrations show a fixed ratio.

Mansfield: It would be possible to ask plant breeders to produce cultivars with different stomatal sensitivities. You could opt to have the same yield as at present, but with a better efficiency of water use, by growing a plant with a large stomatal response to $\mathrm{CO}_{2}$.

Rabbinge: That's right. Some plants in fact behave like that, which means that they profit in terms of efficiency of water use when carbon dioxide is higher.

Mansfield: That might enable you to grow crops in areas that are insufficiently supplied with water unless they are irrigated.

Rabbinge: Or you could reduce the amount of irrigation.

Elliott: You discussed the relationship between $\mathrm{CO}_{2}$ levels and yield, and made the point that this was an ecological correlation and not proof of causality. This is a problem that we face in epidemiology all the time. We often don't have the advantage that you have with crops, that of experimental design. You spend a lot of time on simulation, but rather than relying on simulation, you could actually set up experiments to test these things, which often we can't do in epidemiology.

Rabbinge: What we can do is test the reliability of the models we are using for the feasibility studies in which we use simulation models. The models have been tested at the three levels. They simulate experiments which were done under well-known conditions and the environmental conditions were incorporated into the models. These models gave reliable results, so we decided that they could be used for feasibility studies on climate change, provided that the response of the stomata is like that observed in the detailed experiments. We are therefore confident that the outcomes of the simulations are reliable. On this basis, you can also see what the economic consequences are of a carbon dioxide increase. 
Hoffmann: Are there any assumptions built into your studies about the use of pesticides to control certain pests, to allow maximum productivity, or are the models independent of pesticide usage?

Rabbinge: At the level of individual fields, where we assume the conditions are optimal, the assumption is that pests and diseases are eliminated. This could be done in three different ways, through growing resistant varieties, using biological control measures or using pesticides. At a higher aggregation level, the European Community, land use could be considerably lower than at present; if land use is less, much smaller amounts of pesticides and nitrogen would be used than at present, and the environmental side effects would be decreased. We would be producing on better soils at a higher production level, and would be using external resources more efficiently. This seems to be a little counterintuitive, because we always have the idea that with an increase of a growthstimulating factor, the law of diminishing returns would apply. That's true if you consider only one growth-stimulating factor if all the others are abundant. In agriculture, it's the combination of factors that is important. You should not irrigate if you are not giving nitrogen, and you should not over-use nitrogen if you are not irrigating. If the combination is right, the efficiency of use of each of the resources does not decrease, but increases, or stays more or less the same, when yields perhaps increase. At the higher aggregation level, we have included the concept of 'best technical means', which means that usage of each of the external resources, nitrogen, phosphorous, pesticides or whatever, is the minimum per unit of product, at the same time maximizing the efficiency of use of all the other resources. This system can be developed and applied, and will result in high yields with very low input.

Lake: In the light of the predicted changes we heard about from Professor Oeschger, do you envisage large changes in the nature of land use, or is the existing infrastructure so conservative that we shall stay with the current portfolio of crops but grow them in different ways?

Rabbinge: I would think that the environmental changes, increases in temperature and carbon dioxide, will have less impact on land use than the socioeconomic changes. For example, up to 1958, the countries that formed the European Community imported most of their sugar from other parts of the world, whereas nowadays the EC exports sugar. With the founding of the EC, a fixed, sustained high price for the sugar was guaranteed. If the EC now moves in a more market-orientated direction, we would probably begin to import sugar, and the sugar beet industry would suffer. This would be an example of socioeconomically determined change. The tax-payer might no longer be willing to give so much money to a farming industry which is working in a less efficient way than it could be. That would cause more dramatic shifts in land use, in my opinion, than environmental changes.

James: Your comments have made me understand a little better the basis of the enhanced efficiency you describe. I am still not clear whether you are dealing 
with a theoretical series of assumptions about synergism and efficiency, or whether you have actually shown this in practice. If you have shown it in practice, presumably the extraordinary savings in nitrogen would also apply to phosphate, etc. How do the calculations eventually come out in terms of energy use? My predecessor, Sir Kenneth Blaxter, frequently used to point out that in fact Western agriculture is an incredibly inefficient industry in relation to energy use. Essentially, energy in the form of fossil fuel is being poured into the land for a minute return.

Rabbinge: What is important here is the added energy-machinery, pesticides, fertilizers, etc. If you include the added energy in the computation, the efficiency is higher when yields are high. Being thrifty with external input in a good production situation in fact decreases efficiency rather than increasing it. One should aim to use better soils, high production levels, and low external resources per unit of product tailored to the specific needs of the crop; then you will achieve higher efficiency than in a situation in which there is a lot of spoilage of external resources.

James: A net input is still needed.

Rabbinge: A net input is always needed. If you go back to a situation without inputs, you would be back to the situation that existed more than a century ago, where harvests were not much more than $1500 \mathrm{~kg}$ wheat/ha. To achieve this yield without machinery, you have to use manpower instead, and the resulting efficiency would be even lower. About 370 hours of labour would be needed per hectare of wheat, whereas nowadays in the United States the figure is $6 \mathrm{~h} / \mathrm{ha}$ and in the United Kingdom $15 \mathrm{~h} / \mathrm{ha}$. In Western Europe today wheat yields are $7500 \mathrm{~kg} / \mathrm{ha}$, whereas at the beginning of the century the yield was $1500 \mathrm{~kg} / \mathrm{ha}$. This means that labour productivity has risen 200 -fold over a period of about 80 years.

Oeschger: In Third World countries more than half of the world's population is suffering from famine. Global change should help to improve the living conditions of people from the Third World. How can the techniques you described help people in developing countries now?

Rabbinge: Many techniques are being implemented in many places already. In South-east Asia, and also in India and China, there is rapid development at present, but Africa is far behind. There is not much hope that the dramatic changes which are urgently needed in Africa will happen within 40 or 50 years. The second green revolution took place in Indonesia, India and China. In Indonesia over the last 10 years there has been an average yield increase of $150 \mathrm{~kg} / \mathrm{ha} /$ year. The figures in India and China are similar. This change is needed in view of the growing populations of these countries. In Africa and in some parts of western Asia there is still an urgent need for a green revolution. An enormous input of technology is not needed; what is required is concerted action to adapt and improve the various production systems to enable these countries to buy external inputs. There is more agricultural research going on in Africa than anywhere else, but the results are not successfully implemented, because the farmers are not yet familiar with the technology and do not possess the means to get external resources. 